\title{
THE POTENTIAL OF GEOMATICS IN THE REALIZATION OF A MAP OF DESERTIFICATION SENSITIVITY SOUTHERN MASSIF BELEZMA - BATNA - (ALGERIA).
}

\author{
$\begin{array}{lll}\text { H. Benmessaoud } & \text { F. Chergui } \quad \text { R. Sahnouni } \quad \text { C. Chafai }\end{array}$ \\ Faculté des sciences -Université El Hadj Lakhdar-Batna- Algérie \\ Email : ha123_m123@yahoo.fr Tél.: 002130668292940
}

\section{Commission VI, WG VI/4}

KEY WORDS: Desertification, Massif Belzema, Geomatics, GIS, Cartography theme.

\begin{abstract}
:
Desertification is the gradual and sustained reduction in the quantity and quality of the biological productivity of arid and semi-arid land.

The study area is located in the North Eastern part of Algeria, it has a rich heritage in its biodiversity, however weather conditions and adverse human reality, induce a degradation of the physical environment in the form of a regression of vegetation cover.

To assess desertification in our study area map of desertification sensitivity is a tool for decision support.

For the realization of this Map we used the ArcGis software applied a methodology which is inspired by the concept MEDALUS (Mediterranean Desertification and Land Use, 1999) by crossing four thematic layers that may have an impact on the process of desertification.

The results of Cartography and statistical analysis permit the classification of our region in terms of sensitivity to desertification in four very important classes. (Not affected, Insensitive, Sensitive and highly sensitive).

More than $69.92 \%$ of the surface area were classified sensitive to very sensitive, For against $30.07 \%$ is classified in unallocated insensitive.

Planning restoration work and the fight against desertification are expected to limit the risk of desertification in the study area perspectives.
\end{abstract}

\subsection{Introduction}

Having large parts of its territory under arid and semi-arid areas, Algeria is one of world's most affected countries by desertification. With 2 million square kilometres of desert and 382,000 sq. km-dominated by semi-arid and sub-humid areas, Algeria is the second largest African country as far as the territory is concerned (Abdessemed K., 1981, Berkane and Yahiaou 2007). Desertification has a strong presence in the country; however, the steppe areas are the most sensitive zones to desertification covering about 20 million hectares (Ansar 2002).

Combating thus desertification requires first the acquisition of data, such as soil, biodiversity, socio-economics, etc that are necessary for problem analysis. These data were derived from previous studies (Ballais, 1981, Benmessaoud et al. 2007) and using a GIS were elaborated for desertification impact analyses (Benmessaoud et al. 2007, Bensaid 2006). The GIS proved to be a powerful tool for such purpose.

The region southern massif Belezma has experienced over the last decades rapid degradation of natural resources (Dubois J. M. et al. 1997, PNUD/UNSO DGF/Algérie, 2001, Oussedik et al. 2003).

The degradation process includes wind erosion and sand encroachment, animal and crop product reduction, and migration. Sustainable development of the area thus necessitates the establishment of digital databases and data elaboration for identification of desertification sensitivity areas.

Our work addresses a specific case study in the region south massif Belezma (Eastern Algeria) that was finalised with the completion of a sensitivity to desertification map at medium scale using a GIS system and following the MEDALUS methodology (Mediterranean Desertification and Land Use).

\subsection{Background information}

The southern massif Belezma constitutes a geographical entity located east of the Saharan Atlas Mountain. This whole mountain is very steep and heavily exposed to the process of desertification (erosion), particularly in its southern part that is in direct contact with the Sahara.

Geographically, the study area is located (Figure 1), between the meridians $\left(8^{\circ} 37^{\prime}\right.$ and $\left.5^{\circ} 36^{\prime}\right)$ East and the parallel $\left(35^{\circ} 15^{\prime}\right.$ and $\left.34^{\circ} 41^{\prime}\right)$ North.

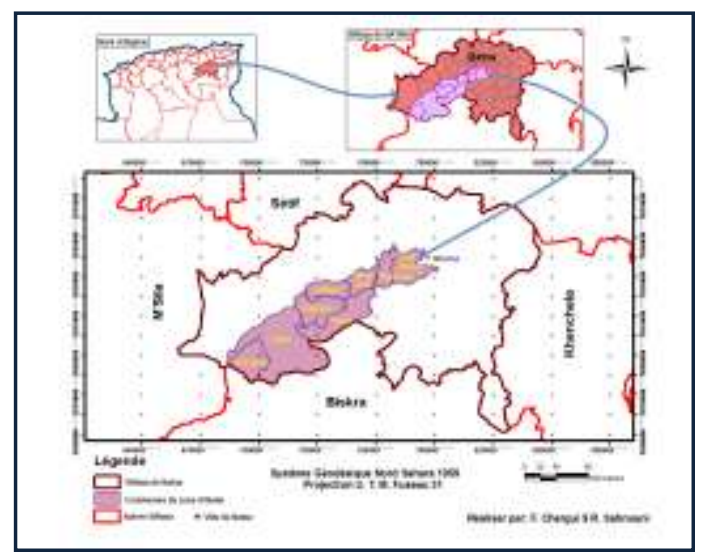

Figure1. Location map of the study area 
The study area is located in a transition zone between the North Atlas and the flat desert expanding in the south. From the climatic point of view the area belongs to the Mediterranean climate and is characterized by hot and dry summers and cold wet winters in the highlands and mild in the plains, however remains generally affected by aridity.

\subsection{Working methodology}

The different types of Environmental Sensitivity Areas (ESA) to desertification could be analysed in relation to various parameters such as landform, soil, geology, vegetation, climate, and human action. Each of these parameters was grouped into various uniform classes with respect to the behaviour on desertification and then weighting factors were assigned to each class. The following four indicators were evaluated (a) soil quality, (b) climate quality, (c) vegetation quality, and (d) management quality. After the computation of four indices for each indicator, the ESAs to desertification were defined by combining the abovementioned indicators. All the data were introduced in a regional GIS, and overlaid in accordance with the developed algorithms to finalise the compilation of ESAs to desertification. This approach includes parameters, which could be easily found in existing soil, vegetation, and climate reports of the area.

\subsubsection{Soil quality indicators}

Soil is a dominant factor of the terrestrial ecosystems in the semi-arid and dry sub-humid zones, particularly through its effect on biomass production. Soil quality indicators for mapping ESAs can be related to (a) water availability, and (b) erosion resistance. These qualities can be evaluated using simple soil properties or characteristics such as texture, parent material, soil depth, slope angle, drainage, stoniness, etc. available in regular soil survey reports the use of these properties for defining and mapping ESAs requires the definition of distinct classes with respect to the degree of land protection from desertification.

Soil quality index (SQI) was then calculated as the product of the above attributes, namely soil texture, parent material, rock fragment cover, soil depth, slope grade, and drainage conditions using as the following algorithm:

\section{SQI $=($ texture * parent material * rock fragment * depth * slope * drainage) ${ }^{1 / 6}$}

Table1. Soil quality index description

\begin{tabular}{|c|c|c|c|}
\hline & Class & Description & Index \\
\hline Soil & & High quality & $<1.13$ \\
Quality & 1 & Moderate & $1.13-$ \\
Index & 2 & quality & 1.45 \\
(SQI) & 3 & Low quality & $>1.46$ \\
& & & \\
\hline
\end{tabular}

Table2. Classes, and assigned weighing indices for the various parameters used for soil assessment

\begin{tabular}{|c|c|c|c|c|}
\hline $\begin{array}{c}\text { SQ } \\
\text { characteristi } \\
\text { cs } \\
\end{array}$ & $\begin{array}{c}\text { Clas } \\
\mathrm{s}\end{array}$ & $\begin{array}{l}\text { Descri } \\
\text { ption }\end{array}$ & $\begin{array}{c}\text { Characteristi } \\
\text { c }\end{array}$ & Index \\
\hline Texture & $\begin{array}{l}1 \\
2 \\
3 \\
4\end{array}$ & $\begin{array}{l}\text { Good } \\
\text { Moder } \\
\text { ate } \\
\text { Poor } \\
\text { Very } \\
\text { poor }\end{array}$ & $\begin{array}{c}\text { L, SAL, SL, } \\
\text { LS, LC } \\
\text { SC, SiL, } \\
\text { SiCL } \\
\text { Si, C, SiC } \\
\text { S }\end{array}$ & $\begin{array}{c}1 \\
1.2 \\
1.6 \\
2\end{array}$ \\
\hline $\begin{array}{c}\text { Parent } \\
\text { material }\end{array}$ & $\begin{array}{l}2 \\
3\end{array}$ & $\begin{array}{l}\text { Good } \\
\text { Moder } \\
\text { ate } \\
\text { Poor }\end{array}$ & $\begin{array}{c}\text { Shale, } \\
\text { schist, basic, } \\
\text { ultrabasic, } \\
\text { conglomerat } \\
\text { es, } \\
\text { unconsolida } \\
\text { ted. } \\
\text { Limestone, } \\
\text { marble, } \\
\text { granite, } \\
\text { Rhyolite, } \\
\text { ignibrite, } \\
\text { gneiss, } \\
\text { Siltstone, } \\
\text { sandstone. } \\
\text { Marl, } \\
\text { Pyroclastics }\end{array}$ & $\begin{array}{c}1.7 \\
2\end{array}$ \\
\hline Slope & $\begin{array}{l}1 \\
2 \\
3 \\
4\end{array}$ & $\begin{array}{l}\text { Very } \\
\text { gentle } \\
\text { to flat } \\
\text { Gentle } \\
\text { Steep } \\
\text { Very } \\
\text { steep } \\
\end{array}$ & $\begin{array}{c}<6 \% \\
6-18 \% \\
18-35 \% \\
>35 \%\end{array}$ & $\begin{array}{c}1 \\
1.2 \\
1.5 \\
2\end{array}$ \\
\hline Drainage & $\begin{array}{l}1 \\
2 \\
3\end{array}$ & $\begin{array}{c}\text { Well } \\
\text { draine } \\
\text { d } \\
\text { Imperf } \\
\text { ectly } \\
\text { draine } \\
\text { d } \\
\text { Poorly } \\
\text { draine } \\
\text { d } \\
\end{array}$ & $\begin{array}{l}- \\
- \\
-\end{array}$ & $\begin{array}{c}1 \\
1.2 \\
2\end{array}$ \\
\hline Soil depth & $\begin{array}{l}1 \\
2 \\
3 \\
4\end{array}$ & $\begin{array}{c}\text { Deep } \\
\text { Moder } \\
\text { ate } \\
\text { Shallo } \\
\text { w } \\
\text { Very } \\
\text { shallo } \\
\text { w }\end{array}$ & $\begin{array}{c}>75 \\
75-30 \\
15-30 \\
<15\end{array}$ & $\begin{array}{l}1 \\
2 \\
3 \\
4\end{array}$ \\
\hline
\end{tabular}




\subsubsection{Climate quality}

Climate quality was assessed using parameters that influence water availability to the plants such as the amount of rainfall, air temperature and aridity, as well as any climate hazards such as frost that might inhibit or even prohibit plant growth. Annual precipitation was classified in three classes considering the annual precipitation of $250 \mathrm{~mm}$ as a crucial value for soil erosion and plant growth (Table 3).

Table 3. Classes and weighing indices for climate quality assessment

\begin{tabular}{|c|c|c|}
\hline & Class $(\mathbf{m m})$ & Index \\
\hline \multirow{3}{*}{ Rainfall } & $>500$ & 1 \\
& $250-500$ & 2 \\
& $<250$ & 3 \\
\hline \multirow{5}{*}{ Aridity } & $<50.0$ & 1 \\
& $50-75$ & 1.1 \\
& $75-100$ & 1.2 \\
& $100-125$ & 1.4 \\
& $123-150$ & 1.8 \\
& $>150$ & 2 \\
\hline
\end{tabular}

The most effective measure for assessing soil water availability is by calculating the difference between precipitation and evapotranspiration and run-off. However, this calculation requires relatively large amount of data such as soil moisture retention characteristics and vegetation growth characteristics. Therefore, the simple BAGNOULS-GAUSSEN aridity index was used. This index was grouped into six classes as shown in Table 3. Slope aspect was divided into two classes (a) NW and $\mathrm{NE}$ and (b) SW and SE assigning the indices 1 and 2, respectively. The above three attributes were then combined to assess the three climate quality index classes (CQI) shown in Table 4 using the following algorithm:

$$
\text { CQI }=(\text { rainfall } * \text { aridity } * \text { aspect })^{1 / 3}
$$

Table 4. Climate quality index

\begin{tabular}{|c|c|c|}
\hline Class & Description & Range \\
\hline 1 & Very favourable & $<1.15$ \\
\hline 2 & Favourable & 1.15 to 1.81 \\
\hline 3 & Unfavourable & $>1.81$ \\
\hline
\end{tabular}

\subsubsection{Vegetation quality}

Vegetation quality was assessed in terms of (a) fire risk and ability to recover, (b) soil erosion protection (c) drought resistance and (d) plant cover. The existing dominant types of vegetation in the Mediterranean region were grouped into four categories according to the fire risk. Four categories were used also for classifying the impacts of vegetation in regard to soil erosion. Four categories were used for the classification of vegetation with respect to drought resistance. Finally, plant cover was distinguished into three classes (Table 6).
Table5. Relationship between type of vegetation and quality index

\begin{tabular}{|c|c|c|c|c|}
\hline & Class & $\begin{array}{l}\text { Descripti } \\
\text { on }\end{array}$ & $\begin{array}{c}\text { Type of } \\
\text { vegetation }\end{array}$ & Index \\
\hline Fire risk & $\begin{array}{l}1 \\
2 \\
3\end{array}$ & $\begin{array}{l}\text { Low } \\
\text { Moderate } \\
\text { Very high }\end{array}$ & $\begin{array}{l}\text { Sand, and Chott } \\
\text { Sebkha } \\
\text { Course, Hills, } \\
\text { Culture, Forest }\end{array}$ & $\begin{array}{c}1 \\
1.3 \\
2\end{array}$ \\
\hline $\begin{array}{c}\text { Erosion } \\
\text { protection }\end{array}$ & $\begin{array}{l}1 \\
2 \\
3\end{array}$ & $\begin{array}{c}\text { Very high } \\
\text { Moderate } \\
\text { Low }\end{array}$ & $\begin{array}{l}\text { Mountainous } \\
\text { Course, Hills, } \\
\text { Culture } \\
\text { Sand, and Chott } \\
\text { sebkha }\end{array}$ & $\begin{array}{c}1.3 \\
1.8 \\
2\end{array}$ \\
\hline $\begin{array}{l}\text { Drought } \\
\text { resistance }\end{array}$ & $\begin{array}{l}1 \\
2 \\
3 \\
4\end{array}$ & $\begin{array}{c}\text { High } \\
\text { Moderate } \\
\text { Low } \\
\text { Very low } \\
\end{array}$ & $\begin{array}{l}\text { Sand, and Chott } \\
\text { sebkha } \\
\text { Course, Hills. } \\
\text { Cultures, Forest. }\end{array}$ & $\begin{array}{c}1.2 \\
1.4 \\
1.7 \\
2 \\
\end{array}$ \\
\hline Plant cover & $\begin{array}{l}1 \\
2 \\
3\end{array}$ & $\begin{array}{c}\text { High } \\
\text { Low } \\
\text { Very low }\end{array}$ & $\begin{array}{c}>40 \\
10-40 \\
<10\end{array}$ & $\begin{array}{c}1 \\
1.8 \\
2\end{array}$ \\
\hline
\end{tabular}

The vegetation quality index (VQI) was assessed as the product of the above vegetation characteristics related to sensitivity to desertification using the algorithm below. The VQI index was classified into three classes defining the quality of vegetation with respect to desertification sensitivity (Table 6).

\section{VQI $=($ fire risk $*$ erosion protection * drought resistance * vegetation cover) $1 / 4$}

Table 6. Vegetation quality Index

\begin{tabular}{|c|c|c|c|}
\hline & Class & Description & Range \\
\hline Vegetation quality & 1 & High quality & $1.2-1.6$ \\
index & 2 & Moderate quality & $1.7-3.7$ \\
VQI & 3 & Low quality & $3.8-16$ \\
\hline
\end{tabular}

\subsubsection{Management quality or degree of human induced stress}

To be able to assess the impacts of management quality and human induced stress the land was classified in the following categories according to the major land use patterns of the study area:

1. Agricultural land: Cropland and Pasture

2. Natural areas: Forest, shrubland and bare land

3. Mining areas (quarries, mines, etc.)

4. Recreation areas (parks, compact tourism development, tourist areas, etc.)

5. Infrastructure facilities (roads, dams, etc.)

After defining the main land use type in a certain piece of land, then the intensity of land use and the enforcement of policy on environmental protection were assessed for each particular type of land use for any specific area. The management quality index (MQI) was assessed using the following algorithm and the results are presented in Table 7 . 
Table 7. Management quality index

\begin{tabular}{|c|c|c|c|}
\hline & Class & Description & $\begin{array}{c}\text { Range } \\
\text { index }\end{array}$ \\
\hline $\begin{array}{c}\text { The management } \\
\text { quality index } \\
\text { (MQI) }\end{array}$ & 1 & High & $1-1.25$ \\
& 3 & Moderate & $1.26-1.50$ \\
& Low & $>1.51$ \\
\hline
\end{tabular}

\subsubsection{Matching results}

The final step comprised the matching of the physical environmental qualities (soil, climate, vegetation) and the management quality for the definition of the various types of ESAs to desertification. The four derived indices are multiplied for the assessment of the ESAs index (ESAI) as following:

$$
\mathrm{ESAI}=(\mathrm{SQI} * \mathrm{CQI} * \mathrm{VQI} * \mathrm{MQI})^{1 / 4}
$$

The ranges of ESAI for each of type of the ESAs (as they were defined above), included three subclasses in each type as they appear in Table 8. Each type of ESAs is defined on a threepoint scale, ranging from 3 (high sensitivity) to 1 (lower sensitivity) in order that the boundaries of the successive classes of ESAs could be better integrated. It must be pointed out that the range for each type of ESAs has been adjusted in such a way that it could include the various types of ESAs resulted from the various studies conducted in the past in the target area of the south Aurès.

Table8. Types of ESAs and corresponding ranges of indices

\begin{tabular}{|c|c|c|}
\hline Types of ESAs & Description & Ranges of indices. \\
\hline 1 & Non affected & $0-1,22$ \\
\hline 2 & Potential & $1,23-1,30$ \\
\hline 3 & Fragile & $1,31-1,41$ \\
\hline 4 & Critical & $1,41-2$ \\
\hline
\end{tabular}

\subsection{Results and interpretation}

Following are detailed analyses of obtained results for the study area.

\subsubsection{Analysis of soil quality}

SQL queries and simple queries were made and after each query was executed the table request was updated until finally the entire database was validated and these results were shown in three soil qualities classes for a total area of $2,501 \mathrm{~km}^{2}$ that are distributed as follows (Table 9 and Figure .3).

Table 9. Distribution of soil quality areas

\begin{tabular}{|c|c|c|c|}
\hline SQI & Description & $\begin{array}{c}\text { Area } \\
(\mathrm{sq} \mathrm{km})\end{array}$ & $\begin{array}{c}\text { Area } \\
(\%)\end{array}$ \\
\hline$<1.33$ & High quality & $1,341.00$ & $53.63 \%$ \\
\hline $\begin{array}{c}1.33 \text { à } \\
1.45\end{array}$ & Moderate quality & 595.47 & $23.81 \%$ \\
\hline$>1.45$ & Low quality & 564.96 & $22.56 \%$ \\
\hline
\end{tabular}

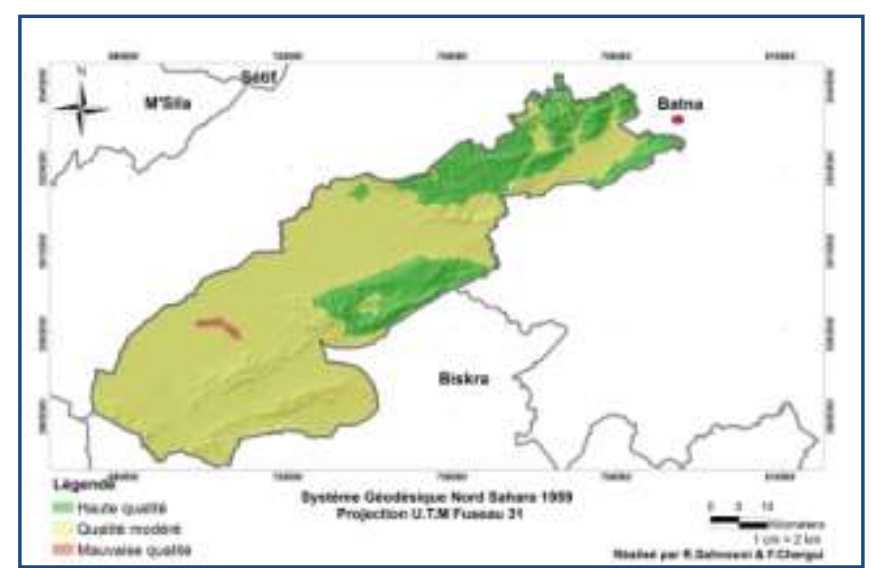

Figure2. Soil quality map of southern massif Belezma

The high soil quality category occupies an area of $1,341 \mathrm{~km}^{2}$ or $53.63 \%$ of the total area, with a quality index below 1.33 . This class is mostly occupied by forest vegetation, is less subject to human pressure than the other two. This explains better soil stability and lower impacts of erosion. The moderate class covers an area of $595.47 \mathrm{~km}^{2}$ or $23.81 \%$ and has an index between 1.33 and 1.45 . It is mostly spread over the central part of the study area. The class of poor quality cover an area of $564,96 \mathrm{~km}^{2}$ or $22.56 \%$ of the total area, with a quality index above 1.45 and it occupies the southern part of the case study.

\subsubsection{Analysis of the climate quality}

Climate quality was shown in three classes and was rather a simpler SQL interpretation compared to the previous soil quality map. Table 8 and Figure 3 show the results.

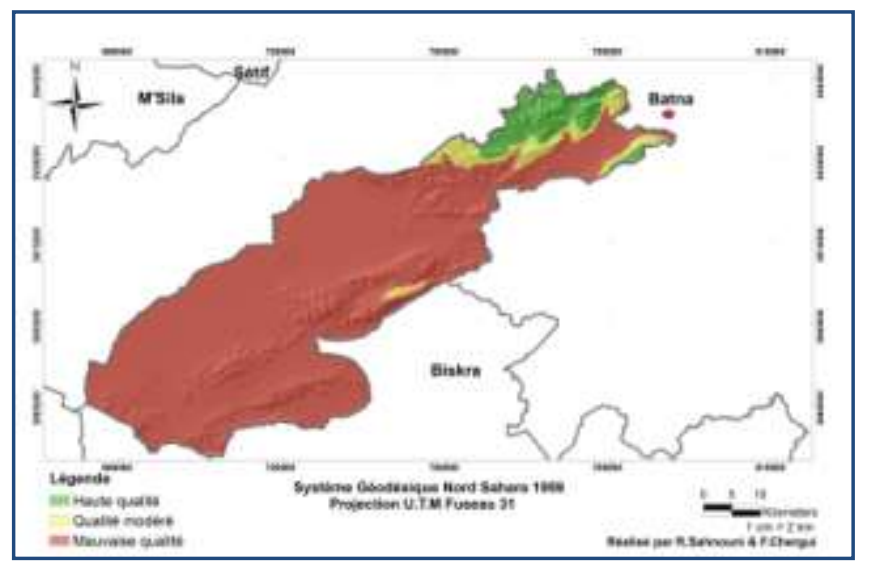

Figure 3. Climate quality map of southern massif Belezma

The very favourable climate class occupy an area of 747,926 $\mathrm{Km} 2$ or $29.91 \%$ of the total area of $2,500.1 \mathrm{~km}^{2}$, with a quality index below 1.34. This class is located in higher altitudes with relatively heavy rainfall. The favourable class covers an area of $744.908 \mathrm{~km}^{2}$ or $29.79 \%$ and has an index between 1.34 and 1.81. It is the biggest of the three categories as the region of south Aurés is located in the arid zone where rainfall does not exceed $200 \mathrm{~mm}$. The unfavourable class extends to the rest of the area, with a quality index above 1.81 and it is spread over the southern part of the case study. 


\subsubsection{Analysis of the vegetation quality}

An SQL analysis was used to establish the areas covered by three classes of vegetation quality to quantify their respective extension areas as they are shown in both Table 9 and Figure 4.

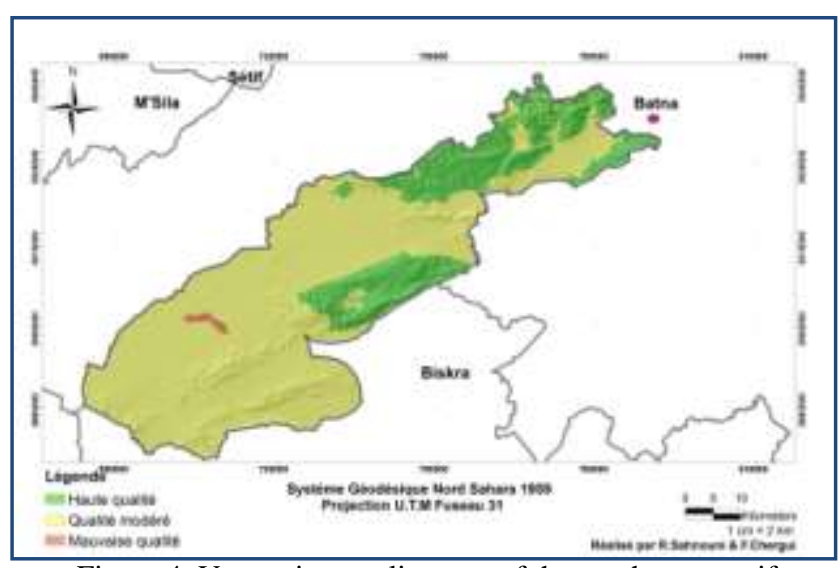

Figure 4. Vegetation quality map of the southern massif Belezma

The area with good vegetation occupies about $24,167 \mathrm{~km}^{2}$ or $0.97 \%$ of the total area, with a quality index below 1.13 . More than $50 \%$ of this class is covered by forest vegetation (scrub oak green). The moderate class quality covers an area of $520.353 \mathrm{Km}^{2}$ or $20.82 \%$ and has an index between 1.13 and 1.38. It occupies the northern part corresponding to the degradation of forests and expansion of crops and pastures. The poor quality class extends to the rest of the area with a percentage of $78.21 \%$, and a quality index above 1.38 . It occupies the southern part.

\subsubsection{Management quality or degree of human induced stress}

The map obtained after treatment with SQL and simple selection made possible to distinguish three socio-economic definition areas given in Table 12 and Figure 6.

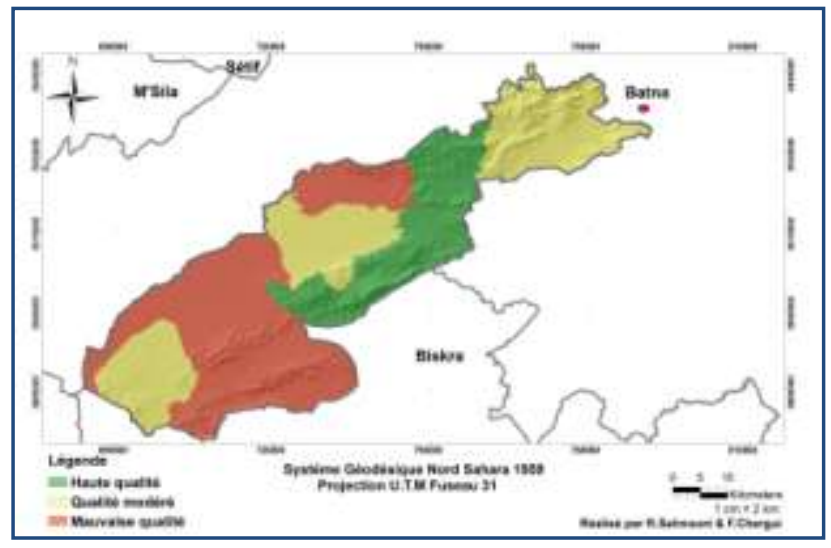

Figure 5. Management quality map of southern massif Belezma

The class of good quality occupies an area de178.551 Km2 or $7.14 \%$, with a quality index between 1 and 1.25 . It is localized mainly in the town of Ain zatout whose population has increased from 3,847 inhabitants in 1987 to 4,000 in 1998 , or an average annual growth rate of $0.36 \%$. This rate is far too low compared to the national average of $2.34 \%$.

The moderate quality class occupies the largest area, or $2,211.44 \mathrm{~km}^{2},(88.44 \%)$ of the total area, with an index between 1.25 and 1.50. This class occupies almost all municipalities in the study area. Vegetables, cereals, fruit trees and phoeniciculture represent the main agricultural production of the area. The poor quality class covers an area of $110,575 \mathrm{~km}$ 2 or $4.42 \%$ out of the total area, with a quality index above 1.5 . These are predominantly pasturelands with dense population.

\subsection{Analysis and interpretation of the desertification sensitivity map}

The final map produced from the combination of previously described indicators enabled us to understand and classify areas sensitive to desertification in the region of south Aurès. We divided them in four classes i.e. 1 - Highly sensitive, 2 Sensitive, 3 - Insensitive, 4 - Unaffected, as shown on Table 110and Figure 6.

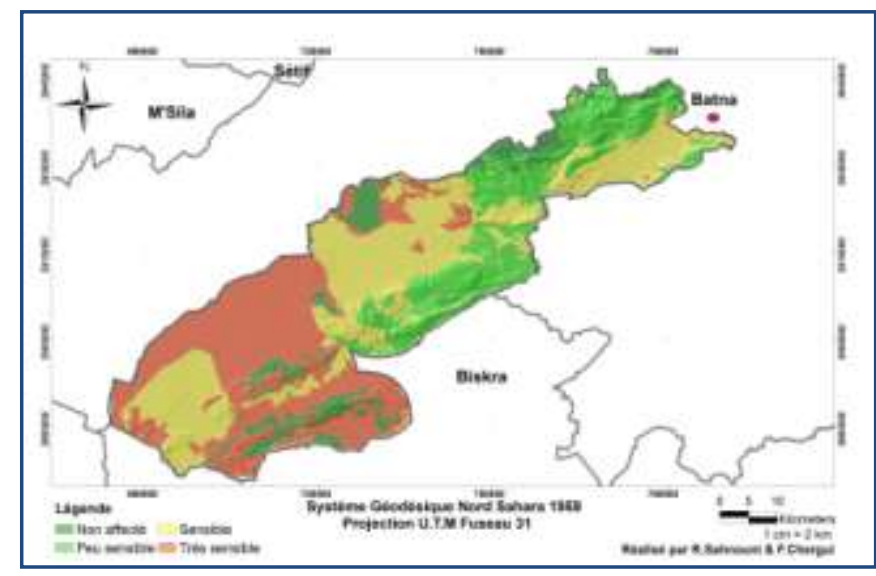

Figure 6. Map of sensitivity to desertification of southern massif Belezma

Table 10. Extension of sensitivity to desertification areas

\begin{tabular}{|l|l|l|l|}
\hline Type & ESAs & $\begin{array}{l}\text { Area }(\mathrm{sq} \\
\mathrm{km})\end{array}$ & $\begin{array}{l}\text { Area } \\
(\%)\end{array}$ \\
\hline Very Sensitive & $1.40-2$ & $1,696.166$ & $67.83 \%$ \\
\hline Sensitive & $1.30-1.40$ & 516.073 & $20.64 \%$ \\
\hline Insensitive & $1.22-1.30$ & 218,406 & $8.73 \%$ \\
\hline
\end{tabular}

Only $2.80 \%$ or $69,921 \mathrm{~km}^{2}$ are included in the unaffected areas with an index of sensitivity between 0 and 1.22 . This class of sensitivity is located north of the study area at the town of Ain zatout in a forest area that have a significant recovery capacity and good conditions for phoeniciculture despite covering a limited surface. The forests consist of Maquis and cover more than $50 \%$ of the territory. The relatively high rainfall reduces drastically the desertification risk.

The Insensitive areas with an extension of $218,406 \mathrm{~km}^{2}$, or 8.73 $\%$ of the total area, have a sensitivity index 1.22 and 1.30 . They are located mainly on the mountain areas north of the case study including the thicket of M'ziraa and M'chouneche, where goat grazing is largely practiced on old maquis accelerating thus the process of forest degradation.

The sensitive class is located in the northern communes. It covers an area of 516,073 square kilometres, or $20.64 \%$ of the total area and the sensitivity index vary between 1.30 and 1.40. 
This sensitivity affects mainly scrub and rangelands and is due to the poor quality of soil, climate and expansion of crops and pastures.

The very sensitive class stretches over an area of about 1,696 $\mathrm{km}^{2}$, or $67.83 \%$ of the total area with an index ranging between 1.40 and 2 . It is very sensitive and occupies the largest part of the case study. It is located mainly in the south and moderately on North West and affects all municipalities in the study area: M'ziraa, M'chouneche, Chetma, Biskra, Bran, and low Djemourah Ain zatout. The desertification process in this part is almost irreversible.

\subsection{Conclusion}

This work has clearly identified the main causes and problems related to desertification in the southern massif Belezma. It also quantified both in spatial and quantitative terms the intensities of desertification. The analysis of results shows that desertification threatens virtually the entire area and appears across various sensitivity classes. In fact over $88 \%$ of the area has been classified as sensitive to very sensitive, while only less than $12 \%$ is included into lower sensitivity classes.

The MEDALUS scientific approach responds well to the identification of desertification sensitivity areas. It could be used also as framework for upgrading results from regional to a larger scale. The approach is based on a number of indicators that need to be evaluated separately than included in thorough evaluation process. All of this has to be supported by the power of GIS. This process starts with data collection in a harmonized basis, which allows assessing the risk of the desertification process and allows developing tools for decision support systems.

\section{REFERENCES}

Abdessemed K., (1981). Le cèdre de l'Atlas (Cedrus atlantica Manetti) dans le massif de l'Aurès et du Belezma - Étude phytosociologique, problème de conservation et d'aménagement. Thèse Doctorat, Université d'AixMarseille.

Ansar A. (2002). L'Aurès Oriental: Un milieu en dégradation .Journal Algérienne des régions arides. Revue semestrielle $\mathrm{N}^{\circ}$ 01, Juin 2002.Ed: C.R.S.T.R.A Biskra (Algérie).

Ballais J.L. (1981). Recherches géomorphologiques dans les Aurès (Algérie). Thèse de doctorat. Paris, Université Paris I.

Berkane A., Yahiaou A. (2007): L'érosion dans les Aurès, Sécheresse vol. 18, $n^{\circ} 3$, juillet-août-septembre 200.

Benmessaoud H., Kalla M., Dridi H., Arar A.K. (2007): Utilisation des SIG pour la réalisation d'une carte de sensibilité à la désertification de la région Sud des Aurès,Algérie. Actes du colloque GEOTUNIS 2007-Tunis du 15 au 17 Novembre 2007.

Bensaid A. (2006). SIG et télédétection pour l'étude de l'ensablement dans une zone aride : le cas de la wilaya de Naâma (Algérie). Thèse de doctorat en géographie, Université Es.Senia, Oran -Algérie-.325p.

Direction générale des forêts (2001). Document de projet d'appui au Plan d'action national Algérie. PNUD/UNSO DGF/Algérie, 2001; 88p.

Dubois J. M. et al. (1997). La réalité de terrain en télédétection: Pratiques et méthodes. Actes des journées scientifiques de Sainte-Foy- Agence Universitaire de la FrancophonieAUPELF-UREF, 356p.
Oussedik A. ,Iftène T., Zegrar A. (2003). Réalisation par télédétection de la carte d'Algérie de sensibilité à la désertification, sécheresse n.02, vol.14, pp 195-201

Schoenenberger. A (1971).Étude du couvert forestier de l'Aurès oriental et inventaire des espèces pastorales du massif des Beni Imloul, Projet Algérie 15, A.D.F, Constantine Agérie. 